\title{
CORPORATE GOVERNANCE The Indian Style
}

\author{
Prof. N.S. Srinivasan *
}

"The History of oriental dynasties is one unceasing round of valour, greatness, discord, degeneracy, decay and death" So wrote the famous $19^{\text {th }}$ century historian Alfred Lyall. This Indian style is very much true in all aspects, be it political dynasties, family business dynasties and even in the way we, Indians, tackle, rather deal with disasters. Take the 26/11, there was the unceasing round of noise, pressures exercised, action to form new NSG commando units atleast in four locations (as if no need was felt before even after the attack on Parliament, and the serial blasts in Mumbai, New Delhi, then Bangalore, and Ahmedabad) It is this 26/11, comparable to the $9 / 11$, that opened our eyes. Now there is the excuse that funds are inadequate, while we can write-off massive farm loans, a way to hide our incompetence and indifference to agriculture and inject massive funds into the financial sector, a way to hide our profligacy but contained by YVReddyism, more so a political opportunism. Today, even after three months, no one knows what is the status of NSG programme. This sensational urgency is dying down and will show its head when another 26/11 shows its head, which is not unlikely. This will be another "dynasty" in the words of Alfred Lyall.

Take Corporate Governance. It is on the same pattern of Lyall's dynasty concept. Quite on the heels of the debacle of Enron and World Com and the collapse of the world's biggest audit firm Arthur Andersen, there was so much enthusiasm to prescribe the norms of corporate governance. In USA, the SAX act was passed in record time, considered as a deterrent in the land of Laissez-faire. In India also, many committees were formed. The recommendations of the KM Birla Committee on the pivotal role of directors, the Narayanamurthy committee on "Independent Directors" and the Nareshchandra Committee on the "Role of Auditors" were all hailed as landmarks for regulating corporate Governance. So much was written, talked and insisted by SEBI directing the appointment of independent directors at $50 \%$ of the board strength, if the chairman is from the promoter group, and $30 \%$ of the board strength, if the chairman is a non-executive director. Alas, all these were only on paper. The steps taken by Mr.Prithvi Haldea to help companies get the quota of independent directors through a special website was rendered frivolous. The very companies that were making a big noise about non-availability of independent directors to SEBI, when approached by Mr.Haldea, came out with $100 \%$ compliance of SEBI directive. This has been possible through a loop- hole in the definition of relative as defined in section 49 of the companies act from the very same companies act in section 6 which states "relative excludes relatives from maternal or wife's side. Such is the quality of companies act, making one feel that these sections

* Senior Management Consultant, Bangalore 
have been set apart so as not to be easily linked. This escape route has been richly cashed by many promoter companies to comply with SEBI directive. In the case of Satyam Computer Services(SCS), one step is ahead. All the five independent directors were not only not related to Raju from either side but all are erudite scholars, highly qualified and authority in their own fields, which helped Ramalinga Raju greatly to put up a façade of excellent corporate governance and went on to get the golden peacock and other awards, not once but on four occasions for excellence in good corporate governance and the last one was as late as 2008. Truly, "Hypocrisy is the Homage that Vice pays to Virtue" . The background of the five independent directors of SCS will be presented later to evaluate how far these five independent directors complied with the requirements in their functions as pronounced by KM Birla Committee and NRN Murthy committee.

The aftermath of Rajus' disclosure brought some revelations from well known and publicly acclaimed independent directors. They went on to state that they are saddled with so many companies directorship, they hardly find time to go through the meeting papers. Very often they pass from one meeting to the other without even looking at the papers. In many cases, the meeting papers, even so called audited financials, are given to them as they enter the board room. What puzzles one is that these directors are to get notice to the meeting before a minimum period, unless they all agree to waive the notice period. Attached to the notice are the agenda, the relevant subject papers and in the case of annual audited accounts for consideration, the same shall be attached to the notice. It is unbelievable and unacceptable that such excuses can be given by these eminent men and get away with, without paying the price for indifference and consequential complicity to all the happenings. If they really felt helpless in such situations, how many of them had the moral courage and ethics of their profession to call it a day with the company, which act would have really rattled the company promoter groups. They can't do that, because they have been adequately taken care of. This is another instance of "Hypocrisy is the homage that vice pays to virtue". Everyone presumed that corporate governance is well settled in India but Satyam case baffles all these and brings out that corporate governance, rather corporate misgovernance, has raised its head manifold in that the five independent directors, along with the other so called watchdog of auditors, have allowed themselves to be privy to all Ramalinga Raju's manifold manipulations over a period of nearly seven long years. This conclusion is based on a number of evidences, lapses allowed to take place, brought out by a series of writers in various magazines .

First let us see what kind of men these five independent directors are.:

Prof. M.Ram Mohan Rao is former Dean of Indian School of Business, Hyderabad. (he was the dean when he voted for the $16^{\text {th }}$ December resolution Prof. Rao was responsible to bring ISB to the internationally acclaimed $20^{\text {th }}$ rank school out of 100 , the one only from India. Not a single IIM could find its place. Before ISB, Prof. Rao was the director of IIMB.

Prof. Krishna Palepu, the Harvard Business School academic and an authority on corporate governance, has co-led HBS corporate governance, leadership and value initiatives.

Mr. Vinod Dham is the father of the Pentium chips .

Dr. Mangalam Srinivasan, a US academician and management consultant, once served the former Prime Minister Indira Gandhi, as her economic advisor.

Mr. T.R. Prasad is the former cabinet secretary. 
Thus, all the five independent directors are highly educated, doyens in their fields, highly respected and there can be no doubt that these five will ever fail in protecting the interests of all stakeholders. Alas, that is what exactly happened. Glimpses of the minutes of the $16^{\text {th }}$ December fateful meeting of SCS Board say that the proposal of the chairman Ramalinga Raju to buy for cash $51 \%$ of Maytas Infra and $100 \%$ of Maytas properties for a combined sum of $\$ 1.6$ billion, rendering SCS's net debt rising by $\$ 400$ million, was unanimously passed by the board. Diverting money from a core business to an unrelated amounts to changing the objects clause of the memorandum of association and that needs shareholders approval in EGM. It is surprising how the qualified company secretary of SCS could keep mum over a serious violation of company law. Whether the independent directors and other members of the board have been apprised of the requirement and if so, the offence committed calls for stringent action on all the directors. If they are ignorant even on fundamental of company law they do not deserve to sit on the board of a publicly listed company, with very high foreign shareholding. It is also gleaned that there was "hesitation" but not "disapproval" from the independent directors to the resolution. All the five are attributed to have raised the question on Raju's sudden diversification move. Mr. Rao, who chaired the meeting, is stated to have called it as "unrelated business". Prof. Krishna Palepu is stated have remarked "creating synergies between different entities might prove a challenger". $\mathrm{He}$ is also stated to have observed that management should make the "same compelling presentation" to the investors. It is said that the most, not subtle, comment came from Dr. Mangalam Srinivasan, cautioning the board not to use the directors as a "rubber stamp". Strangely Vinod Dham was attributed to have stated that it was important to demonstrate how the acquisition would benefit shareholders of SCS. With all these remarks, the resolution to acquire was passed unanimously. It reveals that all the independent directors were mere rubber stamps, so much obliged to Raju that they have thrown to the winds all the ethics, expected of independent directors. Even the age old principle of "At Arms length"in any decision making, particularly when decision makers were to keep high standards of ethics and their accountability is to all stakeholders, were conveniently forgotten. It would not be an uncharitable conclusion to say that the five independent directors were in the know of the fraudulent practices of Raju, since its inception. It would be the next logical step to bring out how it could be .

1. Personality of Ramalinga Raju: The soft spoken, shy Ramalinga Raju is the son of a successful agriculturist (grape farmer). Ohio University B-school graduate and a Harvard alumnus, Raju is a meticulous planner and thought always long term in all his decision making. An old associate of Raju says " Raju invests lot of time in building relationships. He knew all the four independent directors very closely for years." Even when hiring people, he would always spend time to get to know them. The famous former NASCOM president, the late Dewang Mehta was quoted "Raju is a strategist and has an ability to take risks and move at a fast pace" Raju shed most of the other businesses, except construction and took to his hobby, the computer services, seriously. In five years of its listing, by 1995, Satyam computer Services began attracting attention. It had posted $122-$ fold rise in net profit on a top line that had grown 20-fold, since incorporation. Within ten years, Raju metamorphosed SCS into one of the fastest-growing companies in India. In 14 years, it got listed on the New York Stock Exchange (NYSE) and subsequently staked claims to join the billion-dollar club in 2006. All this has been made possible, apart from the ingenuity of Raju, by his close association with the two successive chief ministers of Andra Pradesh. He was on the podium with former US President Bill Clinton. Raju was projected as the rising star of AP like NRN of Infosys . But his thirst for land and construction could not be restrained. He sacrificed his glorious achievements in bringing up SCS, at the altar of greed for land and buildings. "Ambition is made of sterner stuff but it is tyrannous to use it like a giant". 
Atha kena prayukthoyam papam charathi poorusha ha Anitchannapi varshneya baladiva niyojita ha

(Arjuna to Krishna)

Kama ye'sha, krodha ye'sha rajo guna samudbhava ha

(Krishna to Arjuna)

Such is the personality of Raju that every one fell for him

2.Promoters shareholdings: Raju's family held a little more than $21 \%$ in 2001 ; this came down to $17.35 \%$ in 2004 and in 2008 to $8.50 \%$. The minimum required for promoter's management control is $5 \%$. Even that, was non-existent, if the shares pledged with IL\&ES, one the key investors, with whom Raju's have pledged their SCS shares for loans, sold away for margin money when share prices fell steeply. It could be deemed that Raju's, on the day the infamous resolution was passed, were disqualified to manage the affairs of the company. It is required of every listed company to bring out the shareholding pattern in the Balance sheet and in quarterly reports, it is customary to show significant changes. The four independent directors could have easily noticed the sharp decline in promoter holding over the years. Since their accountability is to all stakeholders, they should have pointed out the repercussions of this scenario. But they cannot. Why? It has come to light from an article in one of the magazines that the independent director Vinod Dham had sold his shares at a price of Rs.300/- just two or three months before the historical $16^{\text {th }}$ December board meeting. It is reported in another monthly journal that "internally large scale selling of company shares by institutional investors had gone on for days before Ramalinga Raju's "confessions". It is also brought out "as one digs into the story, one can easily see that many individuals made a killing at Satyam. Investigations will perhaps establish how the killing was made and whether it was through processes which were above-the board. The outgoing CEO and president sold $9,50,000$ satyam shares $(70,000$ indian shares and 2,50,000 ADRs in 2008, when stock prices varied between Rs.300 and 500 per share. The total booty would be around Rs.40 crores. The head of the regional business unit, in the same period, sold 7,10,000 shares and the chief technical officer sold $5,90,000$ shares. Most of these shares were acquired through employee stock options. The sale of shares of this magnitude by executives of SCS would have known to Raju. Who knows, he might have even encouraged. Coming events cast their shadows before. That the board was not aware of happenings is only a lame duck excuse. One can come to the conclusion that the independent directors were witness to the above as their hands were tied up. This is evidenced by the fact that, in the last two years, the independent directors and the auditors received by way of remuneration and commission etc. Rs. 14 crores from SCS. Thus everyone had been silenced and corporate ethics was sacrificed at the altar of greed.

\section{Systematic diversion of SCS funds to family owned} companies: manipulations revealed by Raju: Cooking balance sheet to show cash balance of Rs. 5340 crores, while actual cash balance was only Rs.321 crores; Accrued interest showed Rs.376 crores, but no such income existed; Debtors overstated from Rs.490 crores and Q2-2008 revenue inflated by Rs.588 crores; Liability of Rs.1230 crores, arranged for the company hidden. This is the summary of the revelations made by Raju in his letter to the board.

Let us look at share prices curve from

January 1, 2008 to January 7, 2009:

Jan 1, 08-Rs. 443.60 (Satyam investors

wealth-Rs.29,699.02 crores)

May 30, 08-Rs.523.75; Oct 10, 08-Rs.249.85;

Jan.7, 09- Rs.39.95 (Satyam investors wealth-

Rs.2692.17)

The sale of shares outlined in 1 above have taken place from time to time at the peak prices of Rs. 500 and a low of Rs.300. The shares sold by Mr. Dham, independent director, just two months before the 
$16^{\text {th }}$ December, 2008 meeting, would not be less than Rs.300, indicating he was aware of the shape of things to come and therefore quickly collected the best then available. So is the case of others who sold in lakhs their holding in SCS, as if Raju was preparing to exit from SCS and better to collect as much as from the fallout, like the marauders looting in a big fire outbreak or an earth quake or a train disaster.

3. Raju's manipulations in SCS for his land bank: . Raju hailing from a traditional land owning clan, became infatuated with the idea of cashing on India's booming realty market. Using his closeness to last two chief ministers of AP, Raju acquired large tracts of land through his family owned property firm, Maytas properties and the publicly listed Maytas Infrastructure. To raise cash to pay for the land, Raju used his stake in Satyam (SCS) as collateral. With the realty and stock markets falling and the collaterals sold for margin money and creditors calling back their loans given to Infrastructure, Raju had to face severe cash shortage to the tune of Rs. 7000 crores in SCS. To overcome this, Raju tried to purchase the two Maytas companies for that amount. The deal would have helped Raju to get over the crisis of no real cash in SCS, with Maytas assets forming part of SCS and there was no need to pay the family. In one go, the fake cash of Rs. 5040 crores in the balance sheet will be balanced. Maytas Infrasturcture at this point had a debt of 935.70 crores. Together with the debt of Maytas properties and the new $\$ 400$ miliion required for making good the $\$ 1.6$ billion buyout, the debt position of SCS together with the unrealizable debtors of 2223.41 crores, as they were fictitious, would have totally wiped out the shareholders money. The shareholders hue and cry, including the ADR holders, forced Satyam to back track and finally come up with his confessions.

4. Management control is given to the promoter group, even having only 8 to $10 \%$ holding, for the simple reason that the group knows the business and the business will be run on trust and for the safeguard of the stakeholders interest. Institutional investors own a whopping $62 \%$ (of which $47 \%$ is foreign) and $10.41 \%$ public holding in SCS. Thus, in the case of SCS, it was the fence eating the plant. It is said a due diligence test had been carried out for the purchase proposal. It is confided by one of the directors that a presentation was made with a very strong case for the acquisition by Ram Mynampattti (who later on said he knew nothing), CFO Srinivas Vadlamani and the head of M\&A, Srinivas Satti. They argued that sustained growth in IT was going to be tough, as the sector was dependent on developed markets like the US, where there is a slow down. Normally, such huge cash pile would have been deployed for issuing bonus shares or invested to earn interest. In the case of Infosys, it is transparent that huge sums of cash are with public sector banks, mainly SBI, earning good interest. In the case of SCS, interest income stated to be there was false and the huge cash pile disappeared.

\section{Conclusion:}

a) The four independent directors have been cultivated by Raju over many years. They know Raju intimately, his dynamism, as a great strategist and as one who has achieved phenomenal success in developing SCS as the fourth largest exporter of computer services. In spite of their individual proficiency, they would have been awestruck by the phenomenal performance of Raju. There is, thus, the possibility that they cannot say "No" to Raju on any issue.

b) The four independent directors raised their voices in murmur against the purchase proposal but finally they were unanimous. The fifth was a little more uncharitable when she expressed not to treat the directors as rubber stamp. In reality they were all rubber stamps. Were they aware of the provisions of companies act that the purchase proposal, being not in the line of core business of SCS, it would be violative of the objects clause of the memorandum of association and therefore would call for approval of shareholders in EGM? 
c) It is stated by another director, a former director of IIT Delhi, who appear to be obliged to Raju for the favours shown, that, every quarter, the CFO, the auditors and management would send neatly bound and name embossed reports, certified by the auditors and company fiance department. He didn't elaborate what he did with the reports. Simply because it is certified, did the directors, particularly the independent directors, approve without even opening and looking at the contents, not to speak of any examination and questioning?

d) Since quarterly reports were regularly received and audited annual financials were obviously circulated to all the directors, did the independent directors point out to Raju, from time to time, the dangers of dwindling promoter holding, which would lead to losing management control.

e) The fact that a number of senior executives of SCS were making a kill by selling their shareholding in the company, it is a clear case of insider trading. Normally, the independent directors are expected to bring to the notice of the stakeholders, particularly when $62 \%$ of the shares were held by institutions(with $47 \%$ in foreign hands and $10.41 \%$ held by public). How could one can expect them to report, when one of them cashed his holding, perhaps anticipating the shape of things to come?

f) Did the independent directors ever questioned the wisdom in keeping so much cash in the balance sheet and did they care to verify whether they exist or at least questioned the auditors to bring proof of existence of cash in deposit with banks etc. Did they question the disappearance of cash balance shown in the foreign operations financials in the previous quarter and not appearing in the next quarter. as that would be evident by comparing the balance sheets of two quarters. g) How do one can expect the independent directors to question when they have been remunerated to the extent of Rs. 14 crores in two years along with auditors?

It is clearly evident that the independent directors did not discharge their accountability to the stakeholders and they were privy to the manipulations practiced by Raju in SCS. As such, it is a fit case for bringing the five independent directors, along with others, under the purview of $C B 1$ enquiry to get at the bottom of the truth. They should be asked to return the remuneration they received.

The next pillar of corporate governance is the external auditors, Price, Waterhouse Cooper. (PWC) There is a contention that PWC is not registered with ICAI and therefore cannot undertake any audit of corporate sector in India.. Whatever may be the case, the two so called partners of PWC, who were responsible for audit of SCS all these years, are answerable for all the commissions and omissions, which are innumerable. From the revelations of Raju, it is clear that the auditors never carried out the audits in the way it is expected of every chartered accountant. They never verified the existence of cash balance in the form of deposits with banks and quietly, rather conveniently, accepted balance in banks, without insisting upon a confirmation from each bank. They never reported the disappearance of the cash balance in foreign operations from the balance sheet of such operation. For the year ended 31" March 2008, the gross block was Rs. 1486 crores, while this was shown as R5.2173 crores for the first half of 2008-2009, which quarterly accounts are certified by the auditors vide (c) above of conclusion. Thus there was an increase of R5.413 crores in gross block. It is clarified as the cost of cost of computers and software purchased. As opined by a CFO of another IT rival, "it is never financially wise to make such massive investment in upgrade, especially if you have a cash flow problem. It is possible to divert funds to friendly vendors in this manner". Presuming that Raju decided to give every one of the 53000 employees a computer, each costing Rs.30000/- , the total amount would still be Rs.153 crores, not three times the amount reflected in the balance sheet. Applying depreciation at $50 \%$, the value of the assets 
would be nil in two years. With IT income mostly earned outside the country exempt from tax, there was no room for any verification or compulsion to disclose. The only window is the auditors. They not only failed but were part of the fraud; other wise, how can the payment of a hefty fee of Rs.4.3 crores to PWC be justified. The famous Last words of the auditors of SCS (from Price Waterhouse Cooper's audit report on April 21, 2008) is the height of the hypocrisy practiced:

---In our opinion, the Balance Sheet, Profit \& Loss Account and Cash Flow Statement dealt with by this report comply with the accounting standards referred to in subsection(3c) of section 211 of the Act.

---In our opinion, the company has an internal audit system commensurate with its size and nature of its business.

-.-The company has no accumulated losses as on March 31,2008 and it has not incurred any cash losses in the year ended on that date or in the immediately preceding financial year.

-.-During the course of our examination of books and records of the company, we have neither come across any instance of fraud on or by the company, noticed or reported during the year, nor have we been informed of such case by the management".

The two auditors from PWC have really been true to their salt!!!!

Truly, "Hypocrisy is the homage that vice pays to virtue" The most sorrowful part of the sham is the plight of the employees 53000 in number. Many families would be on the roads, with commitments saddled on their back. This is nothing short of economic murder. Like criminal murder, the economic murder should be dealt with, with imprisonment for life, their properties confiscated. The five independent Directors and the two auditors should be brought under this. PWC would do well to fold up from this country, as they have been privy to the benefits of massive fee from Satyam.

(references- Business World weekly issues, Business

Today, Business India , India Today, Outlook, Indian

Management) 